\title{
Persepsi Kinerja dan Tantangan yang dihadapi Dokter Gigi dalam Praktik
}

\author{
Irene Adyatmaka ${ }^{1}$ \\ ${ }^{1}$ Fakultas Kedokteran Gigi, Universitas Kristen Maranatha \\ Email : irene_al2000@yahoo.com
}

\begin{abstract}
ABSTRAK
Riskesdas 2018 menyebutkan bahwa 21 dari 34 propinsi di Indonesia, penduduknya mengalami masalah gigi dan mulut di atas rerata. Secara nasional, anak usia 5 (lima) tahun memiliki rerata 8 (delapan) gigi rusak. Penduduk usia 65 tahun keatas memiliki 16-17 gigi yang rusak atau bahkan sudah dicabut karena rusak. Di lain sisi, dokter gigi mengeluh praktiknya sepi dari pasien, sangat kontras dengan tingginya angka kerusakan gigi di masyarakat. Tujuan penelitian ini adalah mengetahui persepsi dokter gigi terhadap kinerjanya serta tantangan yang dihadapi di lapangan. Penelitian deskriptif, mixed method dengan potong lintang. Pengambilan sampel secara convenience sampling dengan jumlah subyek studi 409 dokter gigi. Pengambilan data dilakukan Juni 2019. Diurutkan dari besarnya masalah maka dapat diidentifikasi beberapa variabel yang dikeluhkan oleh responden dokter gigi, yaitu: Terkait faktor predisposing dampak pendidikan di FKG: (1) Kurangnya kemahiran menangani pasien balita dengan tantangannya, dirasakan oleh 51\%, (2) Kurangnya kemahiran marketing/pemasaran layanan klinik, 50\%, (3) Kurangnya kemahiran menangani pasien usia lanjut, 43\% (4) Kurangnya kemahiran memotivasi pasien, 26\%, (5) Perasaan yang mendominasi responden saat ini mengenai praktik; Perlu inovasi 53\%. Terkait faktor enabling : (1) Kurang mahir mengelola klinik 40,3\%, (2) Asisten kurang andal, $29 \%$. Terkait faktor reinforcing: (1) Kurangnya Dukungan dinas kesehatan atau pemerintah, 23\%, (2) Kurangnya dukungan organisasi profesi, 16\%. Hasil penelitian dapat memberi masukan tentang kurikulum di Fakultas Kedokteran Gigi sehingga mata ajaran yang diberikan dapat mempersiapkan lulusan memasuki dunia kerja dan segala tantangannya.
\end{abstract}

Kata kunci : persepsi, tantangan, kinerja, dokter gigi, praktik 


\section{PENDAHULUAN}

Riskesdas (Riset Kesehatan Dasar) tahun 2018 menyebutkan bahwa 21 dari 34 propinsi di Indonesia, penduduknya mengalami masalah gigi dan mulut di atas rerata. Secara nasional, anak usia 5 (lima) tahun memiliki rerata 8 (delapan) gigi rusak. Penduduk usia 65 tahun keatas memiliki 16-17 gigi yang rusak atau bahkan sudah dicabut karena rusak. Hanya 2,8\% dari penduduk Indonesia berusia 3 (tiga) tahun ke atas yang sudah memiliki perilaku menyikat gigi dua kali sehari pada waktu yang benar (pagi dan malam). ${ }^{1}$ Target kesehatan gigi yang dicanangkan oleh WHO menyebutkan Global Goals for Oral Health 2020 menyoroti aspek yang luas dari kepenyakitan gigi mulut. Dalam satu tahun mendatang, yang ingin dicapai adalah berkurangnya dampak penyakit gigi mulut dengan penekanan pada promosi kesehatan gigi dan mengurangi beban penyakit gigi mulut di masyarakat, dengan cara early diagnosis (melakukan diagnosa lebih awal), pencegahan dan manajemen efektif penyakit sistemik. $^{2}$

Sistem kesehatan yang baik adalah sistem kesehatan yang terus menerus berusaha mencapai target kesehatan sehingga derajat kesehatan meningkat. Derajat kesehatan yang meningkat sangat terkait dengan pengembangan/ pelayanan sistem kesehatan yang efektif ${ }^{3}$.

Sistem kesehatan yang efektif tidak membuat rumah sakit menjadi overloaded (pasien melebihi kapasitas) sebagai akibat dari ketidakmampuan pelayanan kesehatan dasar (primary care) untuk menahan laju penyakit dari pasien yang datang ${ }^{4}$. Primary care yang baik harus efektif dan efisien, hal ini berkaitan dengan sustainability. Langgeng atau tidaknya kamar praktik seorang dokter gigi berkaitan dengan mutu yang baik, yang kemudian mampu menghasilkan keuntungan keuntungan finansial dari pekerjaan sosialnya. Jika hal tersebut tercapai maka kamar praktik disebut efektif. Efektif berkaitan dengan bagaimana mereka mengelola kamar praktik. Kemampuan dokter gigi memberikan layanan pencegahan akan mampu menghentikan laju penyakit.

Sebuah studi di Benghazi, Libya menemukan bahwa Fakultas Kedokteran Gigi Benghazi tidak mempersiapkan lulusannya menjadi dokter gigi dengan sikap dan keterampilan yang diperlukan untuk melakukan pelayanan yang berorientasi pencegahan, dan karenanya diperlukan perubahan dalam kurikulum. ${ }^{5}$ Fakultas Kedokteran Gigi (FKG) di Indonesia

sudah memiliki kurikulum dengan komponensi kedokteran gigi pencegahan di dalamnya ${ }^{6}$. Saat ini kisaran jumlah dokter gigi lulusan FKG adalah sebanyak 35.000 orang. Namun dengan semakin bertambahnya jumlah FKG dan jumlah dokter gigi, dalam sejarahnya tidak terjadi penurunan masalah kesehatan gigi dan mulut, dan mata kuliah pencegahan belum menjadi hal yang diminati mahasiswa, yang lebih tertarik pada tindakan yang sifatnya kuratif karena dianggap menghasilkan uang ${ }^{7,8}$. Masih banyak dokter gigi mengeluh praktiknya sepi dari pasien, sangat kontras dengan tingginya angka kerusakan gigi di masyarakat. Hal ini menimbulkan pertanyaan besar. Belum ditemukan adanya penelitian di Indonesia yang mengupas apakah dokter gigi yang dihasilkan oleh FKG memang kemudian sesuai kompetensinya dengan permasalahan di lapangan. 
FKG Universitas Kristen Maranatha melihat pencegahan sebagai suatu hal yang penting ditanamkan pada lulusan-lulusannya. Penelitian ini akan menjadi dasar awal untuk membentuk mata ajaran terkait pencegahan yang sesuai dengan kebutuhan dokter gigi. Hingga saat ini belum diketahui gambaran dari situasi kamar praktik dokter gigi di Indonesia. Berdasarkan fakta diatas, maka peneliti merasa perlu untuk melakukan studi evaluasi yang akan mengumpulkan informasi dari lapangan untuk mendapatkan informasi kesesuaian antara kompetensi yang diajarkan selama kuliah di FKG dan kompetensi yang dibutuhkan di lapangan. Teori yang dipakai adalah teori Lawrence Green, sebuah teori yang menganalisis perilaku manusia dipengaruhi oleh faktor perilaku dan faktor diluar perilaku. Perilaku dibentuk dari 3 faktor yaitu faktor predisposisi, faktor pendukung dan faktor pendorong. Penelitian ini akan memperlihatkan tantangan yang dihadapi dokter gigi dalam kinerjanya berkaitan dengan faktor predisposing, enabling dan reinforcing.

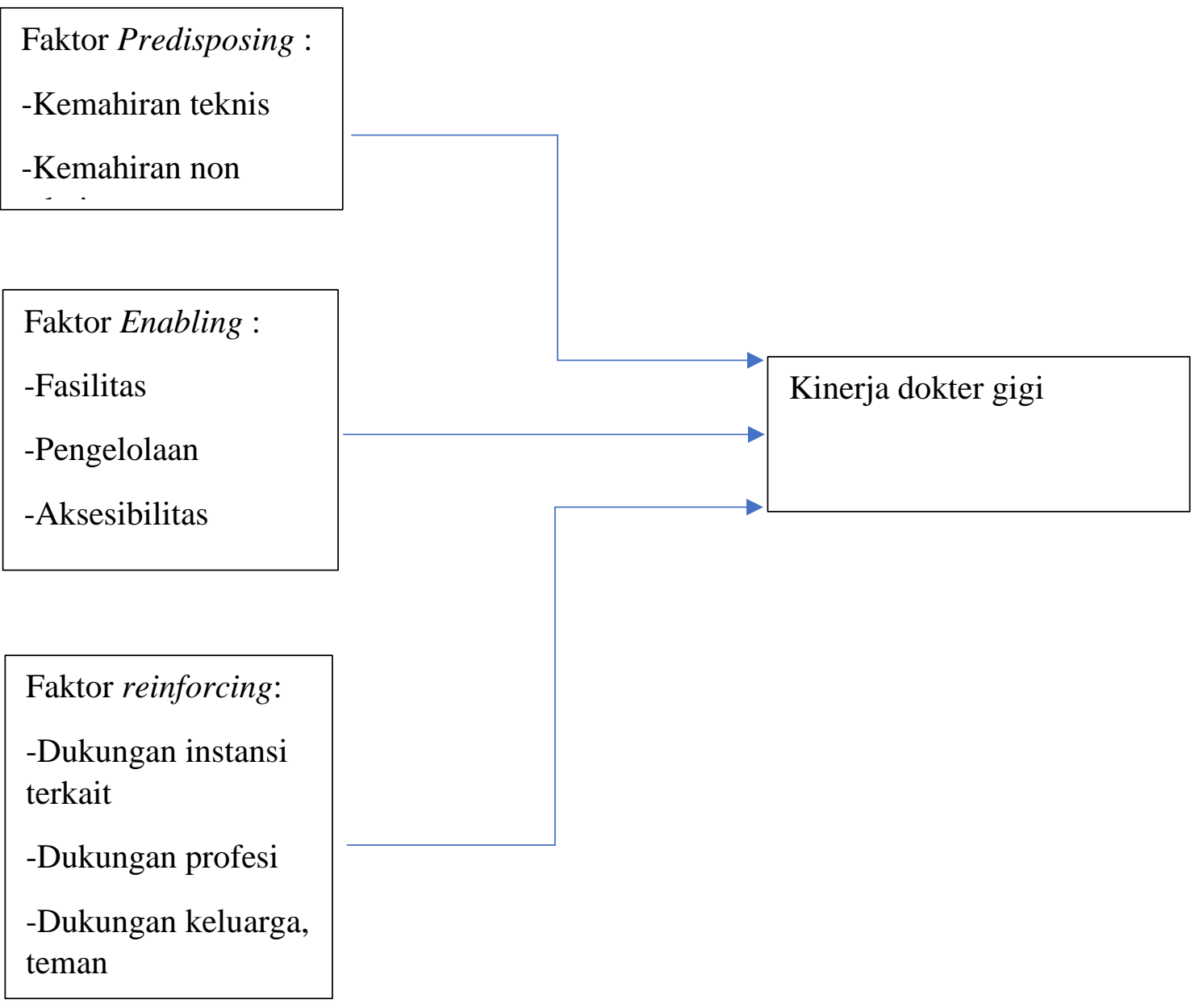

Gambar 1. Kerangka konsep menggunakan teori Green 


\section{METODE PENELITIAN}

Jenis penelitian yang digunakan adalah deskriptif kuantitatif, potong lintang, dengan pengambilan sampel studi dengan metode convenience sampling.

\section{Populasi dan sampel}

Populasi target 18.000 dokter gigi berpraktik aktif. Populasi studi adalah dokter gigi yang mempunyai sosial media whatsapp dan akses survei online.

Penghitungan jumlah sampel berdasarkan perhitungan sebagai berikut :

1. 3600 dokter gigi (20\%) berpraktik purna waktu, $50 \%$ diasumsikan memiliki kinerja baik (estimasi 50\% dilakukan karena tidak ada data)

2. Sisanya 14.400 berpraktik paruh waktu, diasumsikan berkinerja baik lebih sedikit dari pada yang berpraktik purna waktu (yaitu hanya 25\%)

3. Atas dasar hal tersebut didapat perhitungan sampel sejumlah 393 dokter gigi.

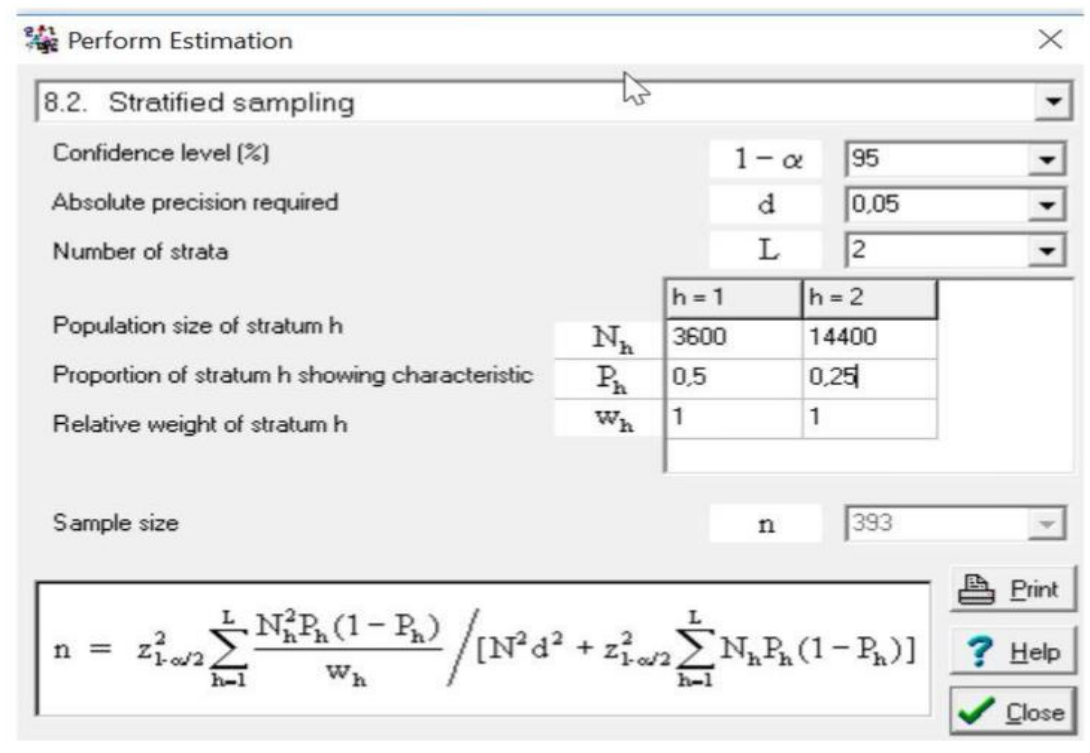

Gambar 2. Penghitungan sampel

Informan penelitian kualitatif 40 orang dokter gigi dengan indepth interview. Kriteria pemilihannya adalah dokter gigi dengan kelompok masa praktek yang berbeda beda, dapat mudah diakses dengan sarana telekomunikasi sms dan telepon, dianggap memiliki wawasan luas dan kritis mengenai permasalahan seputar praktek dokter gigi, merupakan ketua kelompok dokter gigi sehingga bisa dianggap mewakili aspirasi kelompok.

Penelitian ini menggunakan 32 poin pertanyaan kuesioner, dimana 23 poin pertanyaan merupakan pertanyaan yang disusun berdasarkan wawancara mendalam (indepth interview) 
dengan 40 orang dokter gigi, dan 9 (sembilan) poin pertanyaan terkait karakteristik responden atau kondisi praktik responden. Peneliti menggolongkan pertanyaan-pertanyaan tersebut ke dalam beberapa kategori: 7 (tujuh) pertanyaan terkait kinerja dokter gigi dalam melayani pasien (sebagai gambaran praktik dokter gigi); 6 (enam) pertanyaan terkait kemahiran dokter gigi melayani pasien, baik teknis kedokteran gigi maupun non teknis sebagai faktor predisposing dampak pendidikan di Fakultas Kedokteran Gigi; 5 (lima) pertanyaan terkait fasilitas klinik dan pengelolaan serta akses ke masyarakat sebagai faktor enabling; 5 (lima) pertanyaan terkait dukungan dari dinas/ikatan profesi sebagai faktor reinforcing. Ke-11 faktor ini diasumsikan membentuk gambaran praktik dokter gigi.

Pengambilan data dilakukan selama 4 hari mulai tanggal 8 Juni 2019 hingga 12 Juni 2019. Jumlah sampel yang terjaring adalah 409 responden, sehingga telah memenuhi syarat minimal 393 sampel.

\section{HASIL PENELITIAN}

1. Karakteristik responden

Karakteristik responden mewakili proporsi dokter gigi di Indonesia yaitu $80 \%$ perempuan. Responden terbagi dalam 5 kelompok umur dengan persebaran tertinggi berada pada rentang umur 31-50 tahun. Sebanyak 7\% berpraktik di pedesaan, sedangkan $79 \%$ praktik di daerah perkotaan. Responden berasal dari 27 propinsi dengan jumlah terbesar dari Jakarta sebanyak $22 \%$. Responden merupakan alumni dari 20 perguruan tinggi di Indonesia, dengan 46,8\% adalah alumni dari 3 perguruan tinggi di Jakarta. Mayoritas responden bekerja di instansi pada pagi-siang hari dan berpraktik pada malam harinya. Pengalaman praktik cukup bervariasi dengan jumlah yang hampir berimbang di tiap kelompok, namun sebanyak 64\% sudah berpraktik di atas 10 tahun. Sebanyak $86 \%$ responden merupakan dokter gigi umum. Karakterisitik responden dalam penelitian ini dapat dilihat pada tabel 1.1 .

Tabel 1.1. Karakteristik Responden

\begin{tabular}{|c|c|c|}
\hline Kriteria & Jumlah & Persentase \\
\hline \multicolumn{3}{|l|}{ Jenis Kelamin } \\
\hline Laki-laki & 83 & $20 \%$ \\
\hline Perempuan & 322 & $80 \%$ \\
\hline \multicolumn{3}{|l|}{ Usia Responden } \\
\hline 20-30 tahun & 56 & $14 \%$ \\
\hline $31-40$ tahun & 124 & $31 \%$ \\
\hline $41-50$ tahun & 108 & $27 \%$ \\
\hline 51-60 tahun & 81 & $20 \%$ \\
\hline $61-70$ tahun & 32 & $8 \%$ \\
\hline Lokasi Tempat Praktik & & \\
\hline
\end{tabular}


SONDE (Sound of Dentistry) Vol 6 No 2

\begin{tabular}{|c|c|c|}
\hline Perkotaan & 325 & $79 \%$ \\
\hline Pedesaan & 27 & $7 \%$ \\
\hline Pinggir kota (sub urban) & 57 & $14 \%$ \\
\hline \multicolumn{3}{|l|}{ Propinsi Tempat Responden Berpraktik } \\
\hline DKI Jakarta & 90 & $22 \%$ \\
\hline Jawa Barat & 55 & $13 \%$ \\
\hline Banten & 44 & $11 \%$ \\
\hline Jawa Timur & 39 & $10 \%$ \\
\hline Kalimantan Selatan & 35 & $9 \%$ \\
\hline Jawa Tengah & 31 & $8 \%$ \\
\hline Kalimantan Timur & 22 & $5 \%$ \\
\hline Kep. Riau & 22 & $5 \%$ \\
\hline DI Yogyakarta & 10 & $2 \%$ \\
\hline DI Aceh & 7 & $1,7 \%$ \\
\hline Sumatera Utara & 7 & $1,7 \%$ \\
\hline Gorontalo & 6 & $1,4 \%$ \\
\hline Kalimantan Barat & 6 & $1,4 \%$ \\
\hline NTT & 6 & $1,4 \%$ \\
\hline Lampung & 5 & $1,2 \%$ \\
\hline Sumatera Selatan & 4 & $0,9 \%$ \\
\hline Bengkulu & 3 & $0,7 \%$ \\
\hline Riau & 3 & $0,7 \%$ \\
\hline Sulawesi Utara & 2 & $0,5 \%$ \\
\hline Jambi & 2 & $0,5 \%$ \\
\hline Kalimantan Utara & 2 & $0,5 \%$ \\
\hline Kep. Bangka Belitung & 1 & $0,2 \%$ \\
\hline Maluku & 1 & $0,2 \%$ \\
\hline NTB & 1 & $0,2 \%$ \\
\hline Papua & 1 & $0,2 \%$ \\
\hline Sulawesi Tengah & 1 & $0,2 \%$ \\
\hline Sumatera Barat & 1 & $0,2 \%$ \\
\hline \multicolumn{3}{|l|}{ Asal Institusi Lulusan Responden } \\
\hline Universitas Trisakti & 113 & $28 \%$ \\
\hline Universitas Prof. Dr. Moestopo (Beragama) & 47 & $11 \%$ \\
\hline Universitas Gadjah Mada & 46 & $11 \%$ \\
\hline Universitas Airlangga & 42 & $10 \%$ \\
\hline Universitas Indonesia & 32 & $7,8 \%$ \\
\hline Universitas Padjadjaran & 31 & $7,5 \%$ \\
\hline Universitas Hasanuddin & 21 & $5,1 \%$ \\
\hline
\end{tabular}




\begin{tabular}{lrr}
\hline Universitas Sumatera Utara & 19 & $4,6 \%$ \\
Universitas Baiturrahmah & 11 & $2,6 \%$ \\
Universitas Negeri Jember & 11 & $2,6 \%$ \\
Universitas Hang Tuah & 7 & $1,7 \%$ \\
Universitas Lambung Mangkurat & 7 & $1,7 \%$ \\
Universitas Mahasaraswati & 6 & $1,4 \%$ \\
Universitas Syiah Kuala & 5 & $1,2 \%$ \\
Universitas Muhammadiyah Yogyakarta & 4 & $0,9 \%$ \\
Universitas Sriwijaya & 2 & $0,4 \%$ \\
Universitas Sultan Agung & 2 & $0,4 \%$ \\
Universitas Andalas & 1 & $0,2 \%$ \\
Sekolah Tinggi Ilmu Kesehatan Bhakti Wiyata & 1 & $0,2 \%$ \\
Universitas Muhammadiyah Surakarta & 1 & $0,2 \%$ \\
\hline Jenis Praktik & & \\
Praktik pribadi penuh waktu (full time) & 108 & $26 \%$ \\
Praktik swasta bersama sebagai pemilik & 46 & $11 \%$ \\
Praktik swasta bersama sebagai karyawan & 64 & $16 \%$ \\
Puskesmas/instansi pemerintah penuh waktu & 18 & $4 \%$ \\
Instansi di siang hari, praktik pribadi di malam hari & 147 & $36 \%$ \\
Praktik dengan perjanjian saja & 25 & $6 \%$ \\
\hline Lama Pengalaman Praktik & & \\
1-5 tahun & 73 & $18 \%$ \\
6-10 tahun & 68 & $17 \%$ \\
11-15 tahun & 74 & $18 \%$ \\
16-20 tahun 1 -30 tahun & 55 & $13 \%$ \\
31 tahun ke atas & 92 & $22 \%$ \\
\hline Gelar Terakhir & 47 & $11 \%$ \\
Dokter Gigi & & \\
Dokter Gigi Spesialis & 352 & $86 \%$ \\
Doktor, Konsulen & 53 & $13 \%$ \\
\hline Perkiraan jumlah dokter gigi lain yang praktik dalam & 4 & $1 \%$ \\
satu kelurahan dengan responden & & \\
1-5 orang & & \\
6-10 orang & & \\
Di atas 10 orang & $31 \%$ \\
Tidak tahu & $20 \%$ \\
\hline & $39 \%$ \\
\hline
\end{tabular}


2. Gambaran tantangan praktik dokter gigi melalui indikator kinerja

Untuk mendapat gambaran mengenai tantangan yang dihadapi pada praktik dokter gigi, peneliti menggunakan 7 indikator kinerja yaitu (1) pertambahan pasien baru dalam 6 bulan terakhir, (2) banyaknya pasien yang kembali untuk pengobatan kasus yang lain, (3) banyaknya pasien yang menyelesaikan perawatan hingga tuntas, (4) banyaknya pasien yang datang atas rekomendasi pasien lain, (5) banyaknya pasien yang mematuhi instruksi dokternya, (6) banyaknya pasien yang mampu bayar sesuai yang ditagihkan, serta (7) banyaknya pasien yang membawa anggota keluarganya berobat.

Kinerja dokter gigi dapat diukur idealnya dengan pertambahan pasien baru. Sebanyak $79 \%$ responden menyatakan terdapat pertambahan pasien baru sebanyak $25 \%-50 \%$. Pertambahan pasien baru sebanyak $25 \%$ ini merupakan batas kewajaran. Permasalahannya adalah, ada $10 \%$ responden menyatakan bahwa pasiennya tidak bertambah, bahkan makin berkurang, dengan kata lain Klinik Gigi Mandiri Dokter gigi tidak berhasil berkembang. Pertambahan Jumlah Pasien Baru Dalam 6 Bulan Terakhir dapat dilihat pada tabel 2.1.

Tabel 2.1. Pertambahan Pasien Baru - 6 Bulan Terakhir

\begin{tabular}{lccc}
\hline \multicolumn{1}{c}{ Kriteria } & Jumlah & Persen & Kumulatif \\
\hline 0\%, bahkan pasien lama berkurang & 40 & $10 \%$ & $10 \%$ \\
Bertambah 25-50\% & 282 & $69 \%$ & $79 \%$ \\
Bertambah 51-75\% & 70 & $17 \%$ & $96 \%$ \\
Bertambah 76-100\% & 17 & $4 \%$ & $100 \%$ \\
\hline & Total & 409 & $100 \%$ \\
\hline
\end{tabular}

Kinerja dokter gigi dapat diukur idealnya dengan adanya pasien lama kembali untuk keluhan yang lain. Sebanyak 53\% responden mengaku $25 \%-50 \%$ pasien lamanya kembali untuk keluhan yang lain. Kedatangan pasien lama untuk keluhan yang lain sebanyak 26\% ini merupakan batas kewajaran. Namun, ternyata terdapat $11 \%$ responden yang mengaku bahwa pasien lamanya tidak kembali untuk keluhan yang lain. Persentase pasien yang kembali kepada responden untuk berbagai keluhan yang lain dapat dilihat pada tabel 2.2. 
Tabel 2.2 Pasien Lama yang Kembali ke Responden untuk Keluhan Lain

\begin{tabular}{|c|c|c|}
\hline Kriteria & Jumlah & Persen \\
\hline Tidak ada sama sekali, $(0-25 \%)$ & 43 & $11 \%$ \\
\hline $26-50 \%$ & 217 & $53 \%$ \\
\hline $51-75 \%$ & 96 & $23 \%$ \\
\hline $\begin{array}{l}\text { 76-100\% (semua pasien kembali untuk } \\
\text { memeriksakan kondisi yang lain) }\end{array}$ & 53 & $13 \%$ \\
\hline Total & 409 & $100 \%$ \\
\hline
\end{tabular}

Kinerja dokter gigi dapat diukur idealnya dengan melihat seberapa banyak pasien yang menyelesaikan perawatan hingga tuntas. Hanya $36 \%$ responden yang menjawab bahwa 76-100\% pasiennya menyelesaikan perawatan hingga tuntas. Batas di atas $76 \%$ ini merupakan batas kewajaran. Dalam hal ini yang menjadi masalah adalah, sebanyak $64 \%$ responden menyatakan bahwa pasiennya tidak menyelesaikan perawatan hingga tuntas. Persentase pasien yang menyelesaikan perawatan satu giginya hingga tuntas dapat dilihat pada tabel 2.3 .

Tabel 2.3. Pasien yang Menyelesaikan Perawatan Hingga Tuntas

\begin{tabular}{lccc}
\hline & Kriteria & Jumlah & Persen \\
\hline $0-25 \%$ & & 51 & $12 \%$ \\
$26-50 \%$ & & 76 & $19 \%$ \\
$51-75 \%$ & & 133 & $33 \%$ \\
$76-100 \%$ & & 149 & $36 \%$ \\
\hline & Total & 409 & $100 \%$ \\
\hline
\end{tabular}

Untuk pertambahan pasien, idealnya ada pasien yang datang dengan rekomendasi pasien lain. Hal ini penting karena pasien yang puas akan merekomendasikan dokternya pada orang lain. Hasil penelitian menunjukkan sebanyak $43 \%$ responden menyatakan $51 \%$ - 75\% pasien yang datang adalah dengan rekomendasi pasien lain. Batas di atas 51\% ini merupakan batas kewajaran. Maka yang menjadi masalah di sini adalah $43 \%$ responden sisanya tidak memiliki pasien yang datang atas rekomendasi pasien lain. Persentase pasien yang datang dengan rekomendasi dari pasien lain dapat dilihat pada tabel 2.4 . 
Tabel 2.4. Pasien yang Datang dengan Rekomendasi Pasien Lain

\begin{tabular}{|c|c|c|c|}
\hline Kriteria & & Jumlah & Persen \\
\hline $0-25 \%$ & & 55 & $13 \%$ \\
\hline $26-50 \%$ & & 124 & $30 \%$ \\
\hline $51-75 \%$ & & 174 & $43 \%$ \\
\hline $76-100 \%$ & & 56 & $14 \%$ \\
\hline & Total & 409 & $100 \%$ \\
\hline
\end{tabular}

Idealnya semua pasien mematuhi instruksi/anjuran dokter gigi, namun kenyataannya sebanyak 40\% responden mengatakan pasien mematuhi instruksi/anjuran dokter gigi pada kisaran 51\%- 75\%. Batas di atas 51\% ini merupakan batas kewajaran. Yang menjadi masalah $44 \%$ responden mengeluh pasien tidak mematuhi yang intruksi/ anjuran yang diberikan. Persentase pasien yang mematuhi instruksi atau anjuran dari dokter gigi dapat dilihat pada tabel 2.5 .

Tabel 2.5. Pasien Mematuhi Instruksi/ Anjuran Dokter Gigi

\begin{tabular}{lccc}
\hline & Kriteria & Jumlah & Persen \\
\hline $0-25 \%$ & & 47 & $11 \%$ \\
$21-50 \%$ & 134 & $33 \%$ \\
$51-75 \%$ & & 162 & $40 \%$ \\
$76-100 \%$ & & 66 & $16 \%$ \\
\hline & Total & 409 & $100 \%$ \\
\hline
\end{tabular}

Sebanyak $60 \%$ responden mengaku $76 \%-100 \%$ pasiennya mampu membayar sesuai yang ditagihkan. Batas di atas $76 \%$ ini merupakan batas kewajaran. Ini berarti ada masalah dengan $40 \%$ responden dimana pasien tidak mampu membayar sesuai tagihan. Persentase pasien yang mampu membayar sesuai yang ditagihkan dapat dilihat pada tabel 2.6. 
Tabel 2.6. Persentase Pasien yang Mampu Membayar Sesuai yang Ditagihkan

\begin{tabular}{lcc}
\hline \multicolumn{1}{c}{ Kriteria } & Jumlah & Persen \\
\hline $\begin{array}{l}\text { Hanya 0-25\% pasien mampu bayar } \\
\text { sesuai tagihan }\end{array}$ & 14 & $3 \%$ \\
$\begin{array}{l}\text { Hanya 26-50\% pasien mampu bayar } \\
\text { sesuai tagihan }\end{array}$ & 46 & $11 \%$ \\
$\begin{array}{l}51-75 \% \text { pasien mampu bayar sesuai } \\
\text { tagihan }\end{array}$ & 102 & $25 \%$ \\
$\begin{array}{l}76-100 \% \text { pasien mampu bayar sesuai } \\
\text { tagihan }\end{array}$ & 247 & $60 \%$ \\
\hline \multicolumn{1}{c}{ Total } & 409 & $100 \%$ \\
\hline
\end{tabular}

Sebanyak $72 \%$ responden menyatakan $51 \%$ - 75\% pasiennya membawa anggota keluarganya untuk konsultasi maupun berobat kepada responden. Maka batas di atas $51 \%$ ini merupakan batas kewajaran. Masalahnya 30\% responden menyatakan tidak ada pasien yang membawa anggota keluarga. Persentase pasien yang membawa anggota keluarganya untuk konsultasi maupun berobat dapat dilihat pada tabel 2.7.

Tabel 2.7. Persentase Pasien Membawa Anggota Keluarga Berobat

\begin{tabular}{|c|c|c|}
\hline Kriteria & Jumlah & Persen \\
\hline $0-25 \%$ & 31 & $8 \%$ \\
\hline $26-50 \%$ & 92 & $22 \%$ \\
\hline $51-75 \%$ & 172 & $42 \%$ \\
\hline $76-100 \%$ & 114 & $28 \%$ \\
\hline & 409 & $100 \%$ \\
\hline
\end{tabular}

\section{Faktor Predisposing}

\section{Terkait persepsi kemahiran hasil pendidikan}

Peneliti mengukur persepsi kemahiran dokter gigi dalam menangani pasiennya melalui persepsi kemampuannya menangani pasien balita, dewasa, lansia, kemampuan memotivasi pasien, dan kemampuan marketing. Serta dirasakan perlu juga mengukur apa perasaan yang mendominasi responden mengenai praktik.

Diurutkan dari besarnya masalah maka dapat diidentifikasi beberapa variabel yang dikeluhkan oleh responden, yaitu:

1) Kurangnya kemahiran yang dimiliki dalam menangani pasien balita dengan tantangannya (hipersalivasi, mudah muntah, takut, trauma, menangis, perlu dibujuk, dll), $51 \%$ 
2) Kurangnya kemahiran yang dimiliki dalam hal marketing/pemasaran layanan klinik, 50\%.

3) Kurangnya kemahiran yang dimiliki dalam menangani pasien usia lanjut, $43 \%$

4) Kurangnya kemahiran yang dimiliki dalam memotivasi pasien, $26 \%$

5) Kurangnya kemahiran yang dimiliki dalam menangani pasien dewasa, 9,5\%

6) Perasaan yang mendominasi responden saat ini mengenai praktik; Perlu inovasi $53 \%$, membosankan $5 \%$, tidak berani $4 \%$, tidak mampu $1 \%$.

Pada tabel 3.1 disajikan secara lengkap persepsi kemahiran dokter gigi dalam menangani pasien.

Tabel 3.1 Persepsi kemahiran dalam menangani pasien

\begin{tabular}{lrr}
\hline Kriteria & Jumlah & Persen \\
\hline Menangani pasien lanjut usia & & \\
\hline Sulit (0-25\% kasus saja yang dapat ditangani) & 21 & $5 \%$ \\
\hline Kurang (26-50\% kasus dapat ditangani) & 209 & $37 \%$ \\
\hline Mahir (51-75\% kasus dapat ditangani) & 26 & $51 \%$ \\
\hline Sangat mahir (76-100\% kasus dapat ditangani) & 409 & $100 \%$ \\
\hline Total & & \\
\hline
\end{tabular}

Menangani pasien dewasa

\begin{tabular}{lrr}
\hline Sulit (0-25\% kasus saja yang dapat ditangani) & 2 & $0,5 \%$ \\
\hline Kurang (26-50\% kasus dapat ditangani) & 37 & $9,0 \%$ \\
\hline Mahir (51-75\% kasus dapat ditangani) & 274 & $67,0 \%$ \\
\hline Sangat mahir (76-100\% kasus dapat ditangani) & 96 & $23,5 \%$ \\
\hline Total & 409 & $100 \%$ \\
\hline
\end{tabular}

Menangani pasien balita

Sulit (0-25\% kasus saja yang dapat ditangani)

\begin{tabular}{lrr}
\hline Kurang (26-50\% kasus dapat ditangani) & 157 & $38 \%$ \\
\hline Mahir (51-75\% kasus dapat ditangani) & 169 & $41 \%$ \\
\hline Sangat mahir (76-100\% kasus dapat ditangani) & 31 & $8 \%$ \\
\hline Total & 409 & $100 \%$ \\
\hline
\end{tabular}

Kemampuan Memotivasi pasien

Sulit (0-25\% kasus saja yang dapat ditangani)

Kurang (26-50\% kasus dapat ditangani)

$5 \quad 1 \%$

Mahir (51-75\% kasus dapat ditangani)

$102 \quad 25 \%$

$240 \quad 59 \%$




\begin{tabular}{lrr}
\hline Sangat mahir (76-100\% kasus dapat ditangani) & 62 & $15 \%$ \\
\hline Total & 409 & $100 \%$ \\
\hline
\end{tabular}

Kemampuan Marketing / Pemasaran layanan klinik

\begin{tabular}{lrr}
\hline Sulit & 20 & $5 \%$ \\
\hline Kurang & 185 & $45 \%$ \\
\hline Mahir & 184 & $45 \%$ \\
\hline Sangat mahir & 20 & $5 \%$ \\
\hline Total & 409 & $100 \%$ \\
\hline
\end{tabular}

Perasaan yang mendominasi mengenai praktik

\begin{tabular}{lrr}
\hline Membosankan & 19 & $5 \%$ \\
\hline Percaya diri & 166 & $43 \%$ \\
\hline Tidak mampu & 5 & $1 \%$ \\
\hline Tidak berani & 14 & $4 \%$ \\
\hline Perlu inovasi & 205 & $53 \%$ \\
\hline Total & 409 & $100 \%$ \\
\hline
\end{tabular}

\section{Faktor enabling}

Peneliti mengukur faktor enabling melalui ketersediaan listrik pada jam praktik, ketersediaan alat dan bahan, kemahiran manajemen klinik, keterandalan asisten, serta aksesibilitas.

Diurutkan dari besarnya masalah maka dapat diidentifikasi beberapa variabel yang dikeluhkan oleh responden, yaitu:

1) Kurang mahir mengelola klinik $40,3 \%$.

2) Kemampuan / keterandalanan asisten / perawat dalam membantu dokter gigi a) Kurang terbantu / tidak pakai asisten ada $44 \%$.

3) Ketersediaan bahan dan alat yang dibutuhkan di klinik kurang dari $50 \%$ ada $7,8 \%$.

4) Fasilitas listrik di jam praktik kurang dari $50 \%$ hanya 3 responden

5) Kesulitan akses hanya $1 \%$

Penjabaran faktor enabling dapat dilihat pada tabel 4.1.

Tabel 4.1 Faktor enabling praktik dokter gigi

Kriteria Jumlah Persentase

Ketersediaan listrik pada jam praktik 


\begin{tabular}{lrr}
\hline $100 \%$ selalu tersedia & 358 & $87,5 \%$ \\
\hline $75 \%$ tersedia & 48 & $11,7 \%$ \\
\hline $50 \%$ tersedia & 2 & $0,5 \%$ \\
\hline Hanya $25 \%$ tersedia dan bahkan tdk ada & 1 & $0,2 \%$ \\
\hline Total & 409 & $100 \%$ \\
\hline
\end{tabular}

Ketersediaan bahan dan alat yang dibutuhkan di klinik

\begin{tabular}{lrr}
\hline $100 \%$ selalu tersedia & 210 & $51,3 \%$ \\
\hline $75 \%$ tersedia & 167 & $40,8 \%$ \\
\hline $50 \%$ tersedia & 25 & $6,1 \%$ \\
\hline Hanya $25 \%$ tersedia dan bahkan tdk ada & 7 & $1,7 \%$ \\
\hline Total & 409 & $100 \%$ \\
\hline
\end{tabular}

Kemahiran manajemen klinik

\begin{tabular}{lrr}
\hline Sulit & 10 & $2,4 \%$ \\
\hline Kurang & 155 & $37,9 \%$ \\
\hline Mahir & 232 & $56,7 \%$ \\
\hline Sangat mahir & 12 & $2,9 \%$ \\
\hline Total & 409 & $100 \%$ \\
\hline
\end{tabular}

Keterandalan asisten

Sulit (0-25\% kasus saja yang dapat terbantu dengan adanya $\quad 19 \quad 5 \%$ asisten)

\begin{tabular}{lrr}
\hline Kurang (26-50\% kasus dapat terbantu) & 95 & $24 \%$ \\
\hline Mahir (51-75\% kasus dapat terbantu) & 166 & $43 \%$ \\
\hline $\begin{array}{l}\text { Sangat mahir (76-100\% kasus terbantu dg keberadaan } \\
\text { asisten) }\end{array}$ & 71 & $18 \%$ \\
\hline Tidak pakai asisten & 58 & $15 \%$ \\
\hline Total & 409 & $100 \%$ \\
\hline
\end{tabular}

Akses pasien ke tempat praktik responden

\begin{tabular}{lrr}
\hline Secara rata rata Terjangkau dengan mudah & 383 & $94 \%$ \\
\hline $\begin{array}{l}\text { Agak sulit terjangkau karena jarak terlalu jauh dan } \\
\text { transportasi terbatas }\end{array}$ & 20 & $5 \%$ \\
\hline Sulit akses karena letak dan medan yang sulit ditempuh & 2 & $0 \%$ \\
\hline Sulit akses karena waktu tunggu yang terlalu panjang & 4 & $1 \%$ \\
\hline Total & 409 & $100 \%$ \\
\hline
\end{tabular}




\section{Faktor reinforcing terkait dukungan social}

Dukungan yang dirasa kurang/sangat kurang terhadap pekerjaan dokter gigi dalam praktik:

1) Dukungan dinas kesehatan atau pemerintah, kurang/sangat kurang dirasakan oleh $23 \%$.

2) Dukungan organisasi profesi, kurang/sangat kurang ada $16 \%$.

3) Dukungan kolega dari profesi lain, kurang/sangat kurang $7 \%$

4) Dukungan teman sejawat terhadap pekerjaan, kurang/sangat kurang $4 \%$.

5) Dukungan keluarga terhadap pekerjaan, kurang/sangat kurang hanya $1 \%$ (tidak bermasalah).

Tabel 5.1 menyajikan faktor reinforcing pada praktik dokter gigi

Tabel 5.1 Faktor reinforcing pada praktik dokter gigi

Kriteria Jumlah Persentase

Dukungan organisasi profesi terhadap pekerjaan responden

\begin{tabular}{lrr}
\hline Sangat kurang & 16 & $4 \%$ \\
\hline Kurang & 48 & $12 \%$ \\
\hline Baik & 262 & $64 \%$ \\
\hline Sangat baik & 83 & $20 \%$ \\
\hline Total & 409 & $100 \%$ \\
\hline
\end{tabular}

Dukungan Dinas Kesehatan / Pemerintah

\begin{tabular}{lrr}
\hline Sangat kurang & 15 & $4 \%$ \\
\hline Kurang & 79 & $19 \%$ \\
\hline Baik & 262 & $64 \%$ \\
\hline Sangat baik & 52 & $13 \%$ \\
\hline Total & 408 & $100 \%$ \\
\hline
\end{tabular}

Dukungan keluarga

\begin{tabular}{lrr}
\hline Sangat kurang & 3 & $1 \%$ \\
\hline Kurang & 1 & $0 \%$ \\
\hline Baik & 160 & $39 \%$ \\
\hline Sangat baik & 245 & $60 \%$ \\
\hline Total & 409 & $100 \%$
\end{tabular}


Dukungan teman sejawat

\begin{tabular}{lrr}
\hline Sangat kurang & 3 & $1 \%$ \\
\hline Kurang & 12 & $3 \%$ \\
\hline Baik & 247 & $60 \%$ \\
\hline Sangat baik & 147 & $36 \%$ \\
\hline Total & 409 & $100 \%$ \\
\hline
\end{tabular}

Dukungan profesi lain

\begin{tabular}{lrr}
\hline Sangat kurang & 4 & $1 \%$ \\
\hline Kurang & 24 & $6 \%$ \\
\hline Baik & 280 & $69 \%$ \\
\hline Sangat baik & 100 & $25 \%$ \\
\hline Total & 408 & $100 \%$ \\
\hline
\end{tabular}

\section{PEMBAHASAN}

Bila diambil patokan permasalahan yang dikeluhkan lebih dari $1 / 3$ responden $(33,3 \%$ responden) adalah tantangan yang harus diperhatikan, maka berikut ini adalah tantangan yang paling besar ditemui di tempat praktik, yaitu pasien yang tidak menyelesaikan perawatan hingga tuntas dinyatakan oleh $64 \%$ responden (tabel 2.3), pasien tidak mematuhi instruksi/ anjuran dokter gigi dinyatakan oleh $44 \%$ (tabel 2.5), pasien yang datang tidak dengan rekomendasi dari pasien lain dinyatakan oleh $43 \%$ responden (tabel 2.4), serta pasien tidak mampu membayar sesuai yang ditagihkan dikeluhkan oleh $39 \%$ responden (tabel 2.6).

Meski sebagian besar responden adalah dokter gigi dengan pengalaman kuliah sedikitnya 5 tahun dan sudah berpraktik selama lebih dari 10 tahun, namun ternyata tidak 100\% kasus yang ditemui di lapangan serta merta dapat diselesaikan. Sebanyak 51\% responden merasa hanya bisa menangani kurang dari separuh kasus gigi mulut pada pasien balita yang dijumpainya (tabel 3.1). Bahkan pasien dewasa pun hanya bisa ditangani kurang dari 50\% kasusnya pada $9,5 \%$ responden. Sebanyak $42 \%$ responden merasa tidak bisa menangani lebih dari 50\% kasus pada pasien lansia (tabel 3.1). Padahal, menilik hasil Riskesdas 2018, penyakit gigi mulut yang paling sering ditemui adalah penyakit karies, dimana dialami oleh 90\% kelompok umur 5 tahun, 72\% kelompok umur 12 tahun, 68,5\% kelompok umur 15 tahun, $92,2 \%$ kelompok umur $35-44$, serta $95 \%$ orang usia 65 tahun ${ }^{1}$. Karies sebagai penyakit yang dinamis dan bisa dicegah, dimediasi oleh biofilm, diperburuk oleh pola diet yang salah, multifaktor, sehingga menyebabkan hilangnya mineral dari jaringan keras gigi 
dan berakhir sebagai lesi karies ${ }^{9,10}$, ternyata belum sepenuhnya dipahami oleh lulusan dokter gigi, apalagi oleh masyarakat awam.

Faktor predisposing dari masalah dokter gigi di kamar praktik: $43 \%$ responden merasa tidak mempunyai kemahiran dalam menangani pasien usia lanjut, 9,5\% responden merasa tidak memiliki kemahiran dalam menangani pasien dewasa. $51 \%$ responden merasa tidak memiliki kemahiran dalam menangani pasien balita dengan tantangannya. $26 \%$ responden merasa tidak memiliki kemahiran dalam memotivasi pasien, $50 \%$ responden merasa tidak memiliki kemahiran dalam hal marketing / pemasaran layanan klinik, 10\% responden merasa praktik membosankan, tidak mampu, serta tidak berani.

Faktor enabling dari masalah dokter gigi di kamar praktik: 7,8\% responden yang ketersediaan bahan dan alat yang tersedia dibawah 50\%, 40,3\% responden yang merasa kurang mahir dalam mengelola klinik. 24\% responden merasa kurang terbantu dengan adanya asisten bahkan 5\% tidak merasa terbantu. 15\% tidak pakai asisten. Hanya 1\% responden merasa pasien mengalami kesulitan akses.

Faktor reinforcing dari masalah dokter gigi di kamar praktik: dukungan profesi $16 \%$ responden "kurang" /"Sangat Kurang", dukungan dinas kesehatan 19\% yang merasa "kurang" dan 4\% merasa "Sangat Kurang", dukungan keluarga hanya ada 1\% yang merasa "Sangat Kurang", dukungan sejawat 4\% yang merasa "kurang" /"Sangat Kurang", dukungan kolega 7\% yang merasa "kurang"/ "Sangat Kurang".

\section{KESIMPULAN}

1. Tantangan yang dihadapi dokter gigi di kamar praktik : 10\% responden pertambahan pasiennya kurang dari $25 \%$ bahkan pasien lama berkurang, $64 \%$ responden pasien yang tidak menyelesaikan perawatan hingga tuntas, $44 \%$ responden pasien tidak mematuhi instruksi/ anjuran dokter gigi. 43\% responden menyatakan pasien yang datang tidak dengan rekomendasi dari pasien lain, 39\% responden pasien tidak mampu membayar sesuai yang ditagihkan.

2. Selain masalah klinis, memotivasi pasien dirasakan juga menjadi masalah tersendiri. Hal ini dirasakan oleh $26 \%$ responden yang merasa hanya bisa memotivasi kurang dari separuh pasien pasiennya. Bahkan $44 \%$ responden merasa tidak sampai separuh pasiennya yang bisa dibuatnya mematuhi instruksinya. Ketimpangan juga terlihat karena ternyata hanya $60 \%$ responden yang merasa $75-100 \%$ pasien dapat membayar sesuai yang ditagihkan.

3. Fakultas Kedokteran Gigi perlu memikirkan bagaimana bisa terus meningkatkan kemahiran calon lulusan pada pencegahan penyakit gigi mulut. Karena ketika penyakit gigi mulut dibiarkan menjadi fase lanjut/ bersifat spesialistik, selain biayanya menjadi semakin mahal ${ }^{11}$, penanganannya ternyata menjadi lebih sulit, bahkan tidak bisa ditolong oleh sebagian besar responden. Hasil penelitian dapat memberi masukan tentang 
kurikulum di Fakultas Kedokteran Gigi sehingga mata ajaran yang diberikan dapat mempersiapkan lulusan memasuki dunia kerja dan segala tantangannya.

4. Dokter gigi juga merasa perlu dibekali dengan ilmu manajemen klinik dan marketing, sedangkan Poltekesgi sebagai penyedia perawat gigi perlu terus mendekatkan diri dengan dokter gigi, mengikuti perkembangan teknologi terbaru, sehingga lulusannya dapat sepenuhnya dirasakan sebagai bantuan yang dapat diandalkan.

5. Dengan masuknya kita pada situasi pandemi Covid-19, dokter gigi perlu melakukan banyak reformasi dan inovasi seperti teledentistry agar dapat terus merespon kebutuhan masyarakat. Re-orientasi perawatan gigi mulut ke arah tindakan yang semakin tidak invasif serta lebih mengutamakan pencegahan merupakan arah baru yang perlu dikuasai dokter gigi ${ }^{12}$.

\section{DAFTAR PUSTAKA}

1. Badan Penelitian dan Pengembangan Kesehatan, Kementerian Kesehatan RI (2018) Laporan Nasional Riskesdas.

2. Hobdell, Martin (2003): Global goals for oral health 2020. International Dental Journal 53, 285-288

3. Peraturan Presiden Republik Indonesia Nomor 72 tahun 2012 Tentang Sistem Kesehatan Nasional

4. Hu, Y., Zhang, Z. (2015): Skilled doctors in tertiary hospitals are already overworked in China. The Lancet Global Health vol 3, issue 12, PE 737

5. Arheiam, A. (2015): Perceived competency towards preventive dentistry among dental graduates : the need for curriculum change. Libyan journal of Medicine vol 10, issue 1.

6. Buku Pedoman Akademik Program Studi Pendidikan Dokter Gigi S1 Fakultas Kedokteran Gigi Universitas Padjajaran (2017), Fakultas Kedokteran Gigi Universitas Padjajaran,

7. Barichello, T. (2005) Today's new dentists face professional challenges and opportunities. J Am Coll Dent. Fall;7 2(3):6-8

8. Yadav, S., Rawal, G. (2016) The current status of dental graduates in India. The Pan African Medical Journal :23:22

9. Lueckel, HM., Ekstrand, KR. (2013): Caries Management-Science and Clinical Practice. Thieme, Stuttgart, New York.

10. Machiulskiene, Vita, et al (2020): Terminology of Dental Caries dan Dental Caries Management: Consensus Report of a workshop organized by ORCA and Cariology Research Group of IADR. Caries Res 54:7-14.

11. FDI (2015) The Challenge of Oral Disease - A Call for Global Action by FDI World Dental Federation. 
SONDE (Sound of Dentistry) Vol 6 No 2

12. Watt, Richard (2020): Covid-19 is an opportunity for reform in dentistry. The Lancet vol 396. 